when an amino-terminal fragment of the glucose transporter is synthesized off a truncated messenger RNA that encodes the first 340 amino acids of the protein and lacks the stop codon. Uptake of this amino-terminal fragment is insensitive to various ionophores, but requires cleavage of high-energy phosphate bonds ${ }^{7}$.

These new findings do not contradict the previous view that movement of proteins into the endoplasmic reticulum is, in fact, co-translational. But they do show that co-translational translocation is not obligatory. As this excludes a strict mechanistic coupling between elongation of a polypeptide chain and its movement across the endoplasmic reticulum, it is now a distinct possibility that proteins move through different membranes by fundamentally the same mechanism. This mechanism is still a mystery, but efforts to unravel it will benefit from the newly developed cell-free endoplasmic reticulum translocation systems from yeast ${ }^{2.3 .6}$. As these systems should allow the molecular analysis of yeast mutants defective in early steps of secretion (see, for example, ref. 21), biochemists have been handed a sharp new scalpel for dissecting the machinery which moves proteins across the endoplasmic reticulum.

Gottfried Schatz is in the Biochemistry Department, Biozentrum, University of Basel, Klingel bergstrasse 70, CH-4056 Basel, Switzerland.

\title{
Archaeology
}

\section{Late Saxon ceramic utensils}

\section{from Richard Hodges}

POTSHERDS - the tableware, cooking pots and storage containers of ancient times appear at first sight to be the least attractive component of archaeological excavations. But the study of ancient ceramics turns out to be surprisingly useful, providing detailed information about past societies (see ref. 1). The significance of this approach is well illustrated by the recent work of Alan Vince ${ }^{2}$ on the mediaeval pottery of London.

The sheer bulk of potsherds unearthed in modern open-area excavations (for example, several tons from the tenth century Viking dig at York in the United Kingdom ${ }^{3}$ ) has resulted in a shift of emphasis in ceramic studies away from distinguishing pottery in terms of its shape and decoration and towards a system based on pottery fabrics - the clay matrix used by the potters. This fabric series can distinguish between the workshops responsible for the pottery production. The approach necessitates identifying the macroscopic features of the clay; if these features are unclear or can be assigned more precisely to a specific source, a microscopic analysis is performed. The commonest technique in this second stage of analysis is ceramic petrology, in which thin sections of the fabric are examined under a petrological microscope. In some cases the exact provenance of the clay is apparent from its mineralogical character; more often the clay has been taken from some indistinctive riverine source and only the potter's 'recipe' can be identified.

There are tons of pottery in the excavations of the Department of Urban Archaeology at the Museum of London, making a typological listing impractical. Therefore, the fabric series was classified using macroscopic and microscopic principles ${ }^{2}$. Each fabric embraces forms which vary according to its date of manufacture.
Potsherds discarded in the Middle Ages offer fascinating patterns of the history of the potter's craft and how and where these low-grade utensils were sold.

The Late Saxon ceramics from London illustrate this point vividly. It is highly debatable whether London was a significant community before King Alfred's time, but with the explosion of urban development in the tenth century London

IMAGE
UNAVAILABLE
FOR
COPYRIGHT
REASONS

A group of Late Saxon shelly ware vessels from various sites in London. Vessels of this type were made from a clay containing abundant fragments of the fossil gryphaea, characteristic of the Jurassic clays of midland England but not of the Thames Basin.

grew rapidly, so by the end of the century it was engaged in international trading. The ceramic history puts some interesting flesh on this skeleton. First, there was no Middle Saxon (pre-Alfredian) potter serving the community; the pots were made only primitively on a hand-rotated wheel. But, with what I have recently described in News and Views as the first English industrial revolution ${ }^{4}$, the role of the potter changed. Vince shows that the well-dated tenth century groups are dominated by so-called shelly wares (see figure). Petrological analysis of this fabric shows that it contains abundant calcareous inclusions typical of clays in the Oxford region. Pit-groups dated dendrochronologically (tree-ring analysis of their timber content) to the first half of the eleventh century demonstrate a marked change in the type of pottery being discarded. The amount of shelly ware was halved and replaced by other 'imported' pots from areas such as East Anglia, and lead-glazed pitchers made in the town of Stamford also appear in eleventh century contexts in London. A distinctive local fabric, Early Mediaeval Ware, shows abundant sand-grains in thin sections and is one of various recipes used by potters operating near the city. By the end of the tenth century the products of as many as a dozen workshops had broken a virtual monopoly. Thereafter, the rise and fall of industries follows an inexorable pattern, punctuated by a succession of imported wares that reveals London's overseas connections.

The definition of fabrics has made it possible to chart the history of England's earliest craftsmen. Vince's study of London ceramics, like his earlier studies of mediaeval pottery in the Midlands, reveals the rapid development of workshops and their adaptive attitudes to widening their range of products. The scale of the industry and its fast expansion also sheds light on the customers of these potters. The large quantities of tenth century pottery from lower-ranking urban dwellings in sites like London and York, as well as from many villages, reflects a voracious demand for mass-produced commodities.

It has previously been suggested that the peasantry of Late Saxon and Mediaeval England, in common with many traditional nineteenth and twentieth century peasant societies, had minimal access to commodities 5 . In the opinion of some historians, feudal arrangements meant that rural populations had little opportunity to take advantage of urban industrial output. It is still too early to generalize definitively from these studies of mainly urban pottery assemblages, but a picture of a highly integrated, prosperous community is emerging. Potsherds provide details of industrial and commercial connections beyond the scope of the written sources. In many ways these fragments constitute a new form of historical epigraphy and to judge from Vince's results in particular, the collection and processing of archaeology's seemingly least interesting objects is well justified. $\square$

\footnotetext{
1. Van der Leeuw, S.E. \& Pritchard, A. (eds) The Man Dimensions of Pottery (University of Amsterdam, 1984).

2. Vince, A.G. Medieval Archaeol. 29, 25 (1985).

3. Hall. R. The Viking Dig (Bodley Head, London, 1984)

4. Hodges, R. Nature News and Views 316, 211 (1985).

4. Hodges, R. Nature News and Views 316,
5. Hilton, R. J. Peasant Stud. 4, 271 (1978)
}

Richard Hodges is a Lecturer in the Department of Archaeology, University of Sheffield, Sheffield S10 2TN, UK. 